\title{
Macroeconomics in Agriculture
}

\author{
John B. Penson, Jr.
}

Economists traditionally define the long run not in terms of months, years, or when we die (the one notable exception is John Maynard Keynes's observation that in the long run, we are all dead) but rather as a time period long enough to allow for full response to changing incentives or where all factors are variable. My colleagues at Texas A\&M University will confirm that all of my faculties are extremely variable, so I guess I have made it to the long run.

Three people have had a major impact on the direction my career has taken. One was my dissertation chairman at the University of Illinois, Dr. Chester Baker. Chet, past president of the American Agricultural Economics Association and Fellow of the Association, was a major innovator in the field of agricultural finance at the micro and macro levels. He argued, for example, that credit is more than an input; it is an integral part of the decisionmaking process. A second was Dr. Walter McMahon, Professor Emeritus of Economics and Medicine at the University of Illinois, a nationally recognized expert in health economics. Walter taught an advanced macroeconomics course that spurred my interest in relationships between markets in a global economy. The third was Dr. G. Edward Schuh, the Hubert Humphrey Professor at the University of Minnesota and AAEA Fellow. I had the opportunity to discuss research opportunities in the macroeconomics of agriculture with Ed while he was with the President's Council of Economic Advisors, a topic he pioneered back in the 1970s.

John B. Penson, Jr. is Regents Professor and Stiles Professor of Agriculture in the Department of Agricultural Economics, Texas A\&M University.
I spent some time reviewing past Lifetime Award Winner seminar papers in preparing my remarks. These papers are largely an introspective view of an individual's experience during his or her career. My approach is somewhat different. It is commonplace today for doctoral dissertations to consist of three papers. Not confusing my remarks with the required quality of a doctoral dissertation, I would like to focus on three facets of a central theme I think merits your consideration. My remarks will focus on three aspects of the macroeconomics of agriculture: (1) macroeconomics in agricultural economics research, (2) macroeconomics in agricultural economics undergraduate curricula, and (3) macroeconomics in agricultural loan portfolio decision making.

\section{Macroeconomics of Agriculture in Research}

My initial experience with macroeconomic models that in one way or another incorporate an agricultural sector began with Leontief's pioneering work with input-output models and Karl Fox's farm-sector equations incorporated into the Federal Reserve's econometric model. The dynamics associated with Fox's efforts were entirely recursive, whereas the Leontief model was fully simultaneous although static. The latter approach captured agriculture's use of inputs from other sectors in the economy as well as the distribution of its output throughout the economy for a particular year. Prices were unaffected by the assumption that each sector's supply was perfectly elastic. Later input-output modeling by Dorfman, Samuelson, and Solow captured the effects of a kinked supply curve reflecting the current capacity of individual sectors, 
whereas others endogenized demand curves and primary input supply curves (Penson and Fulton). Computable general equilibrium models by Hertel and others also capture the role of agriculture in the general economy. Karl Fox's early contribution to the Federal Reserve's econometric macroeconomic model, based largely on lagged relationships, was eventually broadened in studies by Penson and Hughes, and later, by Penson and Taylor, which econometrically captured the simultaneous interrelationship between agriculture and the general economy. Both modeling approaches require substantial time and resources, however, and thus are difficult to sustain (Penson and Gardner).

The agricultural economics literature also includes a broad array of studies focusing on individual aspects of the macroeconomics of agriculture. Examples that come to mind are studies by Schuh, Chambers, and others focusing on the role of exchange rates. Other studies have focused on supply and demand in individual markets, where macroeconomic variables are captured exogenously. I understand that large-scale models require considerable resources to develop and maintain. To this end, sensitivity analysis of appropriate exogenous variables is a reasonable compromise.

The profession has continued to expand its research focus beyond the farm gate over the years to encompass economic activity all along the supply chain for food and fiber products, often in a global context. The titles of our journals today refer to agricultural and applied economics and to resource and environmental economics as opposed to the Journal of Farm Economics. One simply has to browse the topics covered in Choices from one quarter to the next to appreciate the diversity of the scope of research programs in agricultural economics.

\section{Macroeconomics of Agriculture in Undergraduate Curricula}

Agricultural economics departments are fundamentally micro in theory and applications. Although this should not surprise you, it can be argued that a single introductory macroeconomics course focusing entirely on the behavior of the general economy is insufficient. I argue that students majoring in agricultural economics or agribusiness should have a fundamental appreciation for the sensitivity of agriculture and the food and fiber sector to macroeconomic shocks in today's domestic and global economies. Take the simple concept of supply and demand. An understanding of the forces that cause these curves to shift in the food and fiber industry (i.e., incomes, exchange rates, interest rates, and inflation, to name a few) and events and policies that bring these shifts about cannot be found in an introductory macroeconomics course. Is knowing the value of an income elasticity for a commodity enough? Or should our students understand what might cause the denominator to change?

To gain a better understanding of student exposure to macroeconomic instruction, I reviewed the undergraduate curricula in departments of agricultural economics at 15 universities; 10 in the South (Arkansas, Auburn, Florida, Kentucky, Louisiana State University (LSU), Tennessee, Texas Tech, Texas A\&M, North Carolina (NC) State, and Virginia Tech) and five located outside the South (Illinois, Minnesota, Wisconsin, Purdue, and Maryland). All departments surveyed require undergraduate majors to have at least one course in macroeconomics. The focus of this course is on the monetary and real economies at the aggregate level, with little more than anecdotal references to industry-level causes and effects. Some departments rely on one or two introductory courses taught in an economics department. A few departments require an introductory agricultural economics course to supplement micro and macro concepts taught in an economics department. One department relies entirely on micro and macro instruction within the department.

Importantly, only three departments appear to require that students take an intermediate or capstone course in the macroeconomics of agriculture (Florida, Minnesota, 
and Texas A\&M). I argue that students today need to be able to relate global and domestic macroeconomic events to their major. An intermediate course addressing, among other things, the sensitivity of agriculture to macroeconomic shocks in an open economy is seemingly essential to a well-rounded undergraduate curriculum in agricultural economics or agribusiness. Macroeconomics offers one more perspective on the forces bearing on production, marketing, and financial decisions and events in specific markets and along the food and fiber supply chain as we saw during the efforts of the Federal Reserve to fight inflation during the early 1980s and again during the Asian financial crisis in the late 1990s.

\section{Macroeconomics of Agriculture in Lending Decisions}

The concept of "due diligence" and the importance placed on risk management of loan portfolios requires lending institutions to assess their exposure to various forms of risk, including credit risk, when determining their loan-loss reserves and capital requirements. Credit risk is one of the major pillars in the Basel (Switzerland) international capital accords.

Most, if not all, agricultural lending institutions, however, do little in the way of quantifying the sensitivity of future repayment capacity and the probability of default. Whereas finance textbooks by Rose and Fraser, Gup, and Kolari, among others, underscore the need for portfolio-sensitivity analysis, such evaluation is not practiced in the real world of agricultural mortgage lending. I refer you to articles by Boehlje and Lins and by Penson in the Journal of Lending and Credit Risk Management on this subject. More can be done in the areas of data mining existing portfolios, as well as in stochastic simulation of future debt-repayment capacity at the individual borrower and portfolio segment levels. It has been my experience over the years that many lenders make 20- to 25-year mortgage loans with little enforcement of oversight obligations or risk assessment after the loan is made.

Recent events underscore the globalization of markets, including financial markets. Today we see U.S. farmers purchasing farmland in other countries, like Brazil. The responsibilities placed on both lenders and regulators in monitoring the risk associated with agricultural loan portfolios will increasingly require more in-depth analysis. The bottom line is that gains in computing capacity and database availability allow for more sophisticated sensitivity analysis of farm mortgage lending decisions and potential adverse migration in agricultural loan portfolios.

\section{References}

Boehlje, M., and D. Lins. "Managing Stress in the Agribusiness Portfolio," Journal of Lending and Credit Risk Management 82,4(December 1999): $37-42$.

Chambers, R.G. "Agricultural and Financial Market Interdependence in the Short Run." American Journal of Agricultural Economics 66, 1(February 1984):12-24.

Dorfman, R., P.A. Samuelson, and R.M. Solow. Linear Programming and Economic Analysis. New York: McGraw-Hill, 1958.

Fox, K.A. "A Submodel of the Agricultural Sector." Demand Analysis, Econometrics and Policy Models. S.R. Johnson, J.K. Sengupta and E. Thorbecke eds. Ames: Iowa State University Press, 1992.

Fraser, D.R., B.E. Gup, and J.W. Kolari. Commercial Banking: The Management of Risk. St. Paul, MN: West Publishing Company, 1996.

Hertel, T.W. "Partial vs. General Equilibrium Analysis of International Agricultural Trade." Journal of Agricultural Economics Research 3(1993):3-13.

Leontief, W.W. The Structure of the American Economy, 1919-1939, 2nd edition. New York: Oxford University Press, 1951.

Penson, J.B., Jr. "Stress Testing Agricultural Loan Portfolios." Journal of Lending and Credit Risk Management 83,1(February 2000):70-74.

Penson, J.B., Jr, and M.E. Fulton. "Impact of Localized Cutbacks in Agricultural Production on a State Economy." Western Journal of Agricultural Economics 3(1980):107-122.

Penson, J.B., Jr, and B.L. Gardner. "Implications of Macroeconomic Outcomes for Agriculture." 
American Journal of Agricultural Economics (December 1988):1013-1022.

Penson, J.B., Jr, and D.W. Hughes. "Incorporation of General Economic Outcomes in Econometric Projections Models for Agriculture." American Journal of Agricultural Economics 61(1979):151-157.

Penson, J.B., Jr, and C.R. Taylor. "United States Agriculture and the General Economy: Model- ing Their Interface." Agricultural Systems Journal 39,1(January 1992).

Rose, P.S. The Irwin Series in Finance: Commercial Bank Management, 3rd ed. Chicago: Richard D. Irwin Publishing, 1995.

Schuh, G.E. "The New Macroeconomics of Agriculture." American Journal of Agricultural Economics 59(1977):117-125. 